\title{
EFFECT OF NANO-FERTILIZER, SEEDING RATE AND NITROGEN FERTILIZATION ON BARLEY YIELD UNDER SINAI CONDITIONS
}

\author{
E. E. Haasan; A.A. Sarhan; A. B. Gaballah and A.S.M.Ibrahim \\ Dep. of Plant Prod., Fac. of Technol. and Dev., Zagazig Univ., Egypt.
}

\section{ABSTRACT}

The present study was conducted at two field experiments in a private farm at Gilbana Zone in Sinai, East Qantarah District, Ismailia Governorate, Egypt, during the two successive winter seasons 2015/2016 and 2016/2017. This investigation aimed to find out the effect of chemical nitrogen fertilizer levels (15, 30,45 and 60 $\mathrm{kg} \mathrm{N} / \mathrm{fad}$.), barley seeding rate (40,60 and $80 \mathrm{~kg} / \mathrm{fad}$.) and nanofertilizer application on yield and its components of barley. The spiltspilt plot design as a form of the randomized complete block design with three replications was followed.

Application of nano-fertilizer appeared to produce high values in No. of both spike lets and grains per spike as well as the heavy grains/spike, 1000- grain weight and, increased grain yield/fad. Seeding rate of $80 \mathrm{~kg} / \mathrm{fad}$. appeared to produce the highest value in each of number of spikes $/ \mathrm{m}^{2}$ and grain yield/fad. Meanwhile, the seeding rate of $40 \mathrm{~kg} / \mathrm{fad}$. recorded the highest value in each of No. of both spike lets and grains per spike, weight of both grains/spike and 1000-grain. Nitrogen fertilization was very effective on all yield characteristics, so any increase in $N$ levels was followed by a significant increase in each of No of spike lets/spike, grains/spike and spikes $/ \mathrm{m}^{2}$, also increased weight of both grains/spike and 1000-grain weight and grain yield per fa.

Conclusively, these results finally recommend sowing barley with dense seeding rate of $80 \mathrm{~kg} / \mathrm{fad}$. and application of $60 \mathrm{~kg} \mathrm{~N} / \mathrm{fad}$. In addition to application of nano-fertilizer to maximize grain yield/fad. under the experimental site and other likely environmental conditions.

Key words: Barely, Nano fertilizer, Seeding rate, Nitrogen fertilization, yield and yield components .

\section{INTRODUCTION}

Barley has along history of use as human food and animal feed, of health benefits and malting and brewing in many countries around the world (Malcolmson et al. , 2005). 
Nanotechnology improves the nutrient use efficiency and reduces costs of environmental protection, slow-release fertilizers are the excellent replacement to soluble fertilizers (Abobatta, 2018).

Nano-materials are defined as the materials with a single unit between one and a hundred $\mathrm{nm}$ in size in a minimum of one dimension (Liu and Lal, 2015).Nano-fertilizers and slow released fertilizers are appropriate alternatives to conventional fertilizers for gradual and controlled supply of nutrients in the soil (Mousavi-Fadzl and Fadeznia, 2008).

Abdel-Aziz, Heba et al. (2016)demonstrated that at all experimental stages the values of No. of spikelets/ spike, 100 kernel weight, No. of grains/spike, and grain weight / wheat plant were higher in nano-fertilizer treated plants than in normal fertilizer- treated ones. Kandil and Eman (2017) stated that the applied mineral fertilizer, alone, gave the lowest mean values of the studied traits. Spruogis et al. (2018)reported that, fertilization barley with $\mathrm{N}, \mathrm{P}$ and $\mathrm{K}(50-60-70 \mathrm{~kg} / \mathrm{ha})$ and bioorganic nano-fertilizer $0.1-1.0 \mathrm{~kg} / \mathrm{ha}$ sprayed twice increased grain and straw yields, 1000-grain weight. Ghorbanian et al. (2019) found that foliar application of $\mathrm{SiO}_{2}$ nanoparticles achieved the higher value in each of 1000-grain weight, , grain weight/plant andgrain yield /ha compared to those of the control.

Mohammed Ali and Hashem (2012) stated that, the rate of barley seeding $150 \mathrm{~kg} /$ ha gave the highest means in each of tillers number $/ \mathrm{m}^{2}$, harvest index and grain yield ( $\mathrm{kg} / \mathrm{ha}$ ) in both seasons. Tigabu and Asfadw (2016), revealed that using of $100 \mathrm{~kg} / \mathrm{ha}$, gave the highest grain yield (2.78t/ha). Mekonnen (2018) reported that, 1000-grain weight and grain yield of barley were significantly decreased by raising seeding rate to up $100 \mathrm{~kg}$ seed/ ha. Amarjeet et al. (2020) stated that, insignificant variation was recorded in barley No. of grains/spike, 1000-grain weight and grain yield under the recommended seeding rate and $110 \%$ of recommended one. But, the closer spacing of $20 \mathrm{~cm}$ (row to row) produced higher grain yield $(5.45 \mathrm{Mg} / \mathrm{ha}$ ) than the recommended spacing of $22.5 \mathrm{~cm}$ (5.30 Mg ha-1). Bekele et al. (2020) concluded that increment in malt barley seeding rate from 100-175 kg/ha decreased number of kernels/spike by $28.2 \%$, 1000-grain weight by $23.51 \%$. Also, harvest index value showed decrement with increasing seeding rate.

Nitrogen is the key element in achieving consistently high yields in cereals. Nitrogen is a constituent of many fundamental cell components such as nucleic acids, amino acids, enzymes, and photosynthetic pigments. Thus, grain yield of barley varieties is significantly influenced by rate of $\mathrm{N}$ fertilizer that means when assessing grain yield of cultivars in different rate of $\mathrm{N}$ fertilizer in different barely varieties Safina (2010) demonstrated that, No. of grains/spike and straw yield/fad. of some barley genotypes were linearly increased with 
increasing $\mathrm{N}$ level from 50 to 75 and up to $100 \mathrm{~kg} \mathrm{~N} /$ fad. O'Donovan et al. (2011), Jankovic et al. (2011), Shafi et al. (2011), Tigre et al., (2014), Gezahegn and Kefadle (2016), and Seadh et al. (2017) found that, grain yield of barley, grain weight, and tillers /plant were increased by increasing $\mathrm{N}$ rate. Dubey et al. (2018), Morsy et al. (2018), Niguse and Kassaye (2018) and Terefe et al. (2018), demonstrated that, maximum values of number of spikelets/spike No. of grains/spike, 1000-grain weight of barley were recorded with $60 \mathrm{~kg}$ N/ha They added that grain application of yield successively increased with increase in nitrogen level from 0 to $60 \mathrm{~kg} \mathrm{~N} / \mathrm{ha}$.

The analysis of variance revealed that no significant difference among $\mathrm{N}$ levels in harvest index, meanwhile, thousand grain weight increased almost linearly in all varieties with increasing rates of N (.Awulachew, 2019). Kassie and Tesfadye (2019)stated that, as $\mathrm{N}$ rates increased, malting barley grain yield and 1000-grain weight increased. Tanaka and Nakano (2019)reported that, grain yield of barley and 1000-grain weight markedly increased with increasing $\mathrm{N}$ application from 0 to 30 and up to $60 \mathrm{~kg} / \mathrm{ha}$.

Therefore, there is a need to study the effect of nano-fertilizer application, seeding rate and nitrogen fertilization on growth andgrain yield and its components of barely under Sinia conditions.

\section{MATERIALS AND METHODS}

The present study was conducted at two field experiments ina private farm at Gilbana Zone in Sinai, East Qantarah District, Ismailia Governorate, Egypt, under Agronomy branch supervision, Plant production Department, Faculty of Technology and Development, Zagazig University, Egypt, during the two successive winter seasons 2015/2016 and 2016/2017. This investigation aimed to find out the effect of nitrogen fertilizer levels $(15,30,45$ and60 kg $\mathrm{N} /$ fad.), seeding rate (40,60 and $80 \mathrm{~kg} / \mathrm{fad}$.) and nano- fertilizer application (The nano fertilizer contains total nitrogen (N) 19\%, $\mathrm{P}_{2} \mathrm{O}_{5} 19 \%, \mathrm{~K}_{2} \mathrm{O}$ $19 \%, \mathrm{Fe} 0.48 \%, \mathrm{Mg} 0.80 \%, \mathrm{Mn} 0.24 \%$, Zn 0.35\%, B 0.05\%, Cu0.08\%, Amino acids $1.10 \%$, Algarextracts $0.52 \%$, Mo $100 \mathrm{ppm}$ and Co 100ppm) on yield and its components of barley.

The spilt-spilt plot design as a form of the randomized complete block design with three replications was followed. Since ,nano- fertilizer treatments were allotted in the main plots, while the three seeding rates were arranged at random in the sub plots. Whereas, the four nitrogen fertilizer levels were devoted to sub- sub plots. Each sub-sub plot area was $6 \mathrm{~m}^{2}$ [3 $32 \mathrm{~m}$ ].

The preceding crop was maize in both growing seasons, Giza 132 barley cultivar seeds were drilled in rows on November $25^{\text {th }}$ in both seasons. Whole 
sprinkle treatment with nano- fertilizer was applied basally at two equal doses after 20 and 40 days from sowing date, respectively in all treatments. Nanofertilizer was used at the rate of $5 \mathrm{~kg} /$ fad.with concentration of $2 \mathrm{~g}$./water liter at both applications.

The four nitrogen fertilizer levels (ammonium sulfate 20.6\%) were splitted into three equal doses and applied after 20,40 and 60 days from sowing. Sprinkler irrigation method was used. The normal agricultural practices of barley crop were carried out perfectly. The mechanical and chemical analysis of the soil are given in Table (1).

Table (1): Soil mechanical and chemical properties of the experimental sites at $30 \mathrm{~cm}$ soil depth (average of the two seasons).

\begin{tabular}{|c|c|c|}
\hline \multicolumn{3}{|c|}{ Soil properties } \\
\hline $\mathbf{A}$ & Soil particles distribution: & $(\%)$ \\
\hline & Coarse sand & 49.40 \\
\hline & Fine sand & 37.60 \\
\hline & Silt & 7.25 \\
\hline & Clay & 5.75 \\
\hline \multicolumn{3}{|c|}{ Soil texture: Sandy } \\
\hline \multirow[t]{5}{*}{ B } & \multicolumn{2}{|c|}{ Chemical properties: } \\
\hline & \multicolumn{2}{|c|}{ Soil (pH)7.82 } \\
\hline & \multicolumn{2}{|c|}{ Ec $(d s / m) 7.79$} \\
\hline & \multicolumn{2}{|l|}{ Organic matter (\%)0.28 } \\
\hline & \multicolumn{2}{|l|}{ Total CaCO3 (\%) 2.31} \\
\hline$C$ & \multicolumn{2}{|l|}{ Soluble anions concentration (ppm) } \\
\hline & \multicolumn{2}{|l|}{ CL-78.84 } \\
\hline & \multicolumn{2}{|c|}{$\mathrm{HCO}_{3}^{-0.48}$} \\
\hline & \multicolumn{2}{|c|}{$\mathrm{SO}_{4}^{-0.53}$} \\
\hline \multirow[t]{4}{*}{$\mathbf{D}$} & Soluble cautions concentration: & (ppm) \\
\hline & Available N & 5.30 \\
\hline & Available $\mathbf{P}_{2} \mathrm{O}_{5}$ & 3.90 \\
\hline & Available $\mathrm{K}_{2} \mathrm{O}$ & 71.10 \\
\hline
\end{tabular}

\section{Grain yield and its components:}

At harvest which took place after 140 days from sowing, a sample of ten random spikes from each plot were taken and the following characters were determined:

1- Spike length(cm.): It was measured as distance from the base of main spike to the top of spike excluding owns for randomly ten spikes/ plot. 
2- Number of spikelets/ spike: It was determined at harvesting as a mean of ten spikes.

3- Number of grains/ spike: It was counted as an average mean of ten main spikes/ plot.

4- Grain weight (g.)/Spike: It was counted as an average mean of ten main spikes/ plot.

5- Number of spikes/ $\mathbf{m}^{2}$ : Average grain yield $/ \mathrm{m}^{2}$ were estimated for each plot was calculated.

6- 1000-grain weight (g.): It was determined by the mean weight of a random 1000 grain sample of the plot.

The grain yield/ fad was calculated using the yield obtained from 1 meter length of 5 central rows $(1 \mathrm{~m} 2)$.

7- Grain yield (ard./fad.): Average grain yield $/ \mathrm{m}^{2}$ (1met. length of 5 central rows) were estimated for each plot and the yield of grains /fad. (ardab $=120 \mathrm{~kg}$.) was calculated.

The proper statistical analysis of spilt-split design was used combined analysis was /formed for the characters recorded in both season.

The collected data were statistically analyzed using the Analysis of Variance (ANOVA) to detect significance if any at treatment level. Differences among treatments were judged according to Duncan multiple rang test (Duncan, 1955). Means followed by different letters were statistically significant. In the interaction tables, small letters were used to compare means in columns, whereas capital ones were used to compare means in rows, using the COSTAT system for windows, version 6:311 (cohort software, Berkeley, CA, USA).

Regression analyses were conducted and regression equations describing the relationship between the dependent variables and $\mathrm{N}$ rate were fitted. Orthogonal contrasts were used to test for linear and quadratic responses to $\mathrm{N}$ rate.

\section{RESULTS AND DISCUSSION}

\section{Number of spikelets and grains/ spike}

Rerults in Table (2) show the effect of nano-fertilizer application, seeding rate and nitrogen fertilization on number of spikelets and grains/ barley spike in the two seasons .

\section{1. a. Nano-fertilizer effect:}

In the two growing seasons, application of nano-fertilizer produced much more spikelets and grains/ spike. The combined analysis supported this fact. The activity of water after adding nano-materials was increased and $\mathrm{N}, \mathrm{P}$ and $\mathrm{K}$ 


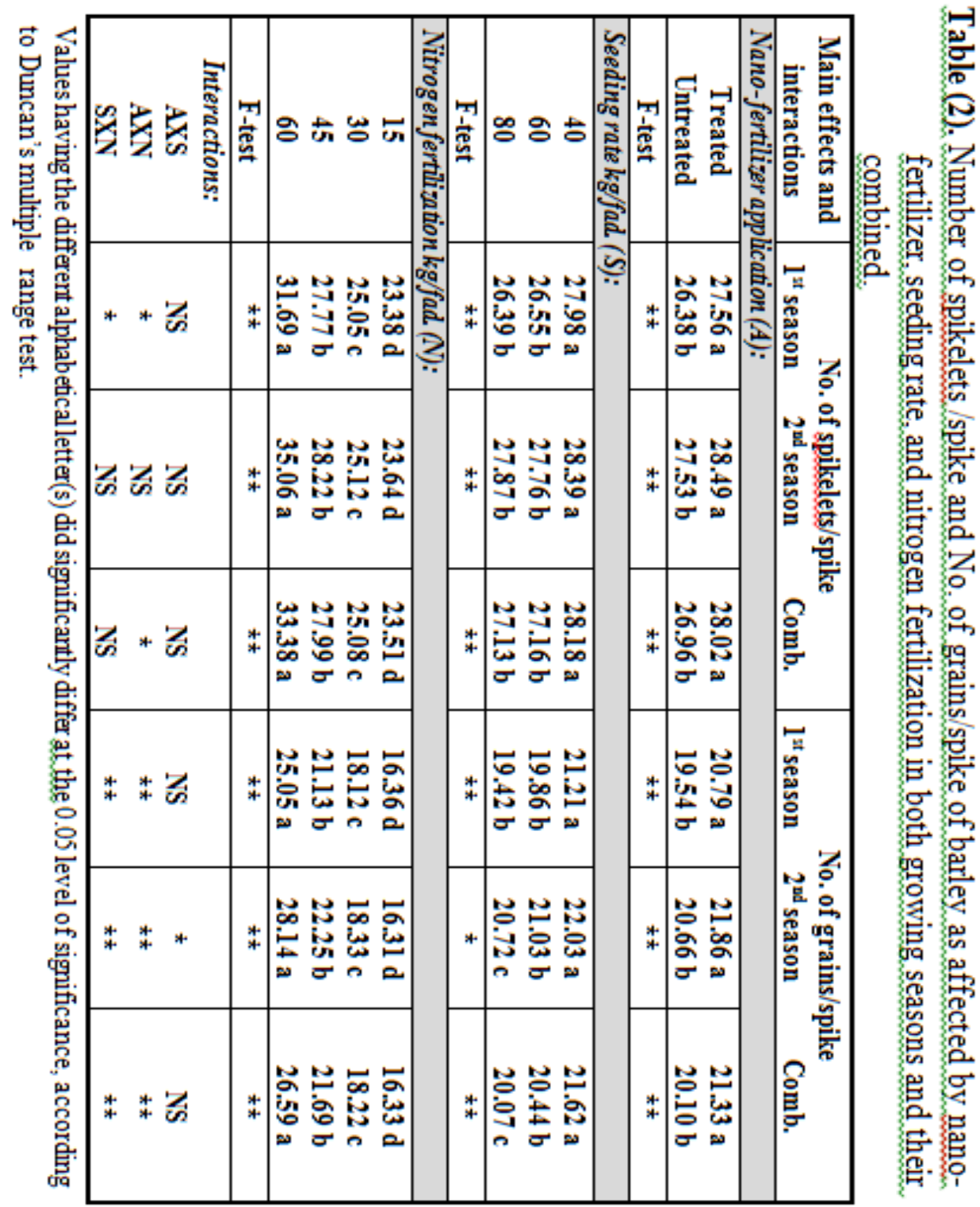


were absorbed by the plants along with the absorbed water, thus the production was also increased. These results are in a good line with those reported by Mardalipour et al.(2014), Abdel-Aziz et al. (2016), Janmohammadi et al.(2016b) and Kandil and Eman (2017).

\section{1. b. Seeding rate effect:}

The lowest seeding rate $(40 \mathrm{~kg} / \mathrm{fad}$.) appeared to produce much more spikelets and grains/ spike as compared with the other two seeding rates. No significant difference between the two heavies seeding rates (60 to 80 $\mathrm{kg} / \mathrm{fad}$.)was observed in number of spikelets /spike in both seasons and their combined., Each increase in seeding rate from 40,60 and up to $80 \mathrm{~kg} / \mathrm{fad}$. was accompanied by a significant decrease in number of grains/spike. This was valid in the 2 nd season and the combined analysis. As seeding rate increased, the number of grains/spike was decreased .Since, grain filling is depended on nutrient supply and environmental condition, increasing plant density resulted in increased competition for nutrients and sunlight at later stages, and finally most grains would fade at early stages, because of competition between growing grains to absorbing reserved matters and as a result low grains would be produced. This result obtained from this study was in line with Yasin and Omar (2013), Assefad et al. (2015) and Bekele et al. (2020).

\section{1. c. Nitrogen fertilization effect:}

Number of spikelets and grains/spike were significantly increased with each increment of $\mathrm{N}$ fertilizer rate up to $60 \mathrm{~kg} / \mathrm{fad}$. This was veridical in both growing seasons and their combined. Increase in the number of grains/spike might be due to better assimilation of carbohydrate in spike.

Assefad et al. (2015) reported that nitrogen increased the number of grains/ spike and this parameter is the best indicator of barley response to nitrogen. Number of grains/ spike had a linear and positive response to $\mathrm{N}$ fertilizer rate. These might be attributed to the ability of the plants that absorb high amount of $\mathrm{N}$ fertilizer, to translocate and assimilate $\mathrm{N}$ for the synthesis and development of spikelet during anthesis phase (Awulachew, 2019). Similarly , Shafi et al. (2011) reported that nitrogen applied at the rate of $60 \mathrm{~kg} / \mathrm{ha}$ resulted in maximum grains/ spike. In this direction similar conclusion were obtained bySafina (2010), Seadh et al. (2017), Dubey et al.(2018) and Terefe et al.(2018).

\section{1. d. Interaction effect:}

The combined results showed that the effect of the interaction between nano-fertilizer and $\mathrm{N}$ fertilization level $(\mathrm{A} \mathrm{x} \mathrm{N})$ as shown in Table (2-a on No. 
Table (2-a).Number of spikelets/spike of barley as affected by the interaction between nano-fertilizer application and nitrogen fertilization (combined data).

\begin{tabular}{|c|c|c|c|c|}
\hline $\begin{array}{c}\text { Nano- fertilizer } \\
\text { application }\end{array}$ & \multicolumn{4}{|c|}{ Nitrogen fertilization (kg N/fad.) } \\
\hline \multirow{2}{*}{ Treated } & D & C & B & A \\
& $23.49 \mathrm{a}$ & $25.74 \mathrm{a}$ & $28.49 \mathrm{a}$ & $34.37 \mathrm{a}$ \\
\hline \multirow{2}{*}{ Untreated } & D & C & B & A \\
& $23.52 \mathrm{a}$ & $24.43 \mathrm{~b}$ & $27.50 \mathrm{~b}$ & $32.38 \mathrm{~b}$ \\
\hline
\end{tabular}

Table(2-b).Number of grains /spike of barley as affected by the interaction between nano-fertilizer application and nitrogen fertilization ( combined data).

\begin{tabular}{|c|c|c|c|c|}
\hline \multirow{2}{*}{$\begin{array}{l}\text { Nano- fertilizer } \\
\text { Application }\end{array}$} & \multicolumn{4}{|c|}{ Nitrogen fertilization (kg N/fad.) } \\
\hline & 15 & 30 & 45 & 60 \\
\hline Treated & $\begin{array}{c}D \\
16.37 \text { a } \\
\end{array}$ & $\begin{array}{c}\mathrm{C} \\
18.90 \mathrm{a} \\
\end{array}$ & $\begin{array}{c}\text { B } \\
22.56 \text { a }\end{array}$ & $\begin{array}{c}\mathrm{A} \\
27.47 \mathrm{a}\end{array}$ \\
\hline Untreated & $\begin{array}{c}C \\
16.30 \mathrm{a}\end{array}$ & $\begin{array}{c}\mathrm{C} \\
17.55 \mathrm{~b}\end{array}$ & $\begin{array}{c}\text { B } \\
20.81 \mathrm{~b}\end{array}$ & $\begin{array}{c}A \\
25.72 \text { b }\end{array}$ \\
\hline
\end{tabular}

of spikelets/spike was inoperative under the lowest $\mathrm{N}$ dose. Whereas, under the three higher dosesthis trait was supreme by application of nano-fertilizer. On the other hand, the increase rate in No. of spikelets/spike due to each increment of $\mathrm{N}$ fertilization was much more higher when nano-fertilizer was applied (3.62) than without nano-fertilizer (2.95).

Concerning the significant interaction effect between nano-fertilizer application and $\mathrm{N}$ fertilization on No. of grains /spike Table (2-b). the results showed similar trends of No. of spikelets. Also, the increase rate in no. of grains/spike due to each addition of level was much more higher under nanofertilizer application (3.70) than without nano-fertilizer application (3.14).

In addition, the significant interaction effect between seeding rate and $\mathrm{N}$ fertilization respecting No. of grains /spike Table (2-c) indicated that the highest grain number ( 28.78 ) achieved by sowing with the lowest seeding rate and application of the highest $\mathrm{N}$ dose. Meanwhile, the lowest grains number/spike was recorded by the sowing with the highest seeding rate as well as application of the lowest $\mathrm{N}$ dose. Under the two lower $\mathrm{N}$ rats, number of grains/spike did not significantly vary due to varying seeding rate. However, under the two higher rates of $\mathrm{N}$ this number was higher when the lowest seeding rate was used. 


\section{Grain weight/spike (g) and No. of spike/m²:}

\section{2. a. Nano-fertilizer effect:}

Both grain weight/spike ( $\mathrm{g}$ ) and No. of spikes $/ \mathrm{m}^{2}$ were significantly superior with application nano-fertilizer compared to without application. This was fact in both growing seasons and their combined. The results of grain weight/spike are in accordance with those reported by Mardalipour et al.(2014), Janmohammadi et al.(2016b) and Ghorbanian et al. (2019). Also, for No. of spikes $/ \mathrm{m}^{2}$ the obtained results are in agreement with those reported by Moaveni et al.(2011), Kandil and Eman (2017) and Morsy et al.(2018).

Table(2-c). Number of grains /spike of barley as affected by the interaction between seeding rate and nitrogen fertilization (combined data).

\begin{tabular}{|c|c|c|c|c|}
\hline \multirow{2}{*}{$\begin{array}{c}\text { Seeding rate } \\
\text { (kg/fad.) }\end{array}$} & \multicolumn{4}{|c|}{ Nitrogen fertilization (kg N/fad.) } \\
\hline & 15 & 30 & 15 & \\
\hline 40 & $\begin{array}{c}\mathrm{D} \\
16.63 \mathrm{a}\end{array}$ & $\begin{array}{c}\mathrm{C} \\
18.70 \mathrm{a}\end{array}$ & $\begin{array}{c}\mathrm{B} \\
22.39 \mathrm{a}\end{array}$ & $\begin{array}{c}\mathrm{A} \\
28.78 \mathrm{a}\end{array}$ \\
\hline 60 & $\begin{array}{c}\mathrm{C} \\
16.57 \mathrm{a} \\
\end{array}$ & $\begin{array}{c}\mathrm{C} \\
18.14 \mathrm{a} \\
\end{array}$ & $\begin{array}{c}\mathrm{B} \\
21.49 \mathrm{~b} \\
\end{array}$ & $\begin{array}{c}\mathrm{A} \\
25.58 \mathrm{~b} \\
\end{array}$ \\
\hline 80 & $\begin{array}{c}\mathrm{D} \\
15.82 \mathrm{a}\end{array}$ & $\begin{array}{c}\mathrm{C} \\
17.84 \mathrm{a}\end{array}$ & $\begin{array}{c}\mathrm{B} \\
21.18 \mathrm{~b}\end{array}$ & $\begin{array}{c}\mathrm{A} \\
25.43 \mathrm{~b}\end{array}$ \\
\hline
\end{tabular}

\section{2. b. Seeding rate effect:}

In both seasons, planting barley by the lowest seeding rate $(40 \mathrm{~kg} / \mathrm{fad}$.) produced the heaviest grains/spike compared to that of the other two seeding rates. Sowing with the lowest seeding rate, resulted maximizing light interception, penetration, distribution in crop canopy and average light utilization efficiency of the leaves in the canopy, and thus effect yield of a plant. These results are confirmed with the results obtained by Noworolnik (2010), Donovan et al.(2011) and Yasin and Omar (2013). Difference between the two higher seeding rates in grain weight/spike did not reach the level of significance. This was the true in both growing seasons and their combined.

Concerning, No. of spikes $/ \mathrm{m} 2$, results revealed that it took the opposite trend so, the heaviest seeding rate give higher spikes number/ $\mathrm{m} 2$ compared to the lowest and moderate seeding rates. Maximum spike numbers in barley were achieved at the highest seeding rate used in every site-year. Such increment in No. of spikes $/ \mathrm{m}^{2}$ due to increasing sowing density could be attributed to increasing number of plants $/ \mathrm{m}^{2}$. These findings are in harmony with those reported by Noworolnik (2010), Yasin and Omar (2013) and Abdel-Hady, Safada (2018). The difference in No. of spikes $/ \mathrm{m}^{2}$ between the two seeding rates (40 and $60 \mathrm{~kg} / \mathrm{fad}$.) was nonentity. 


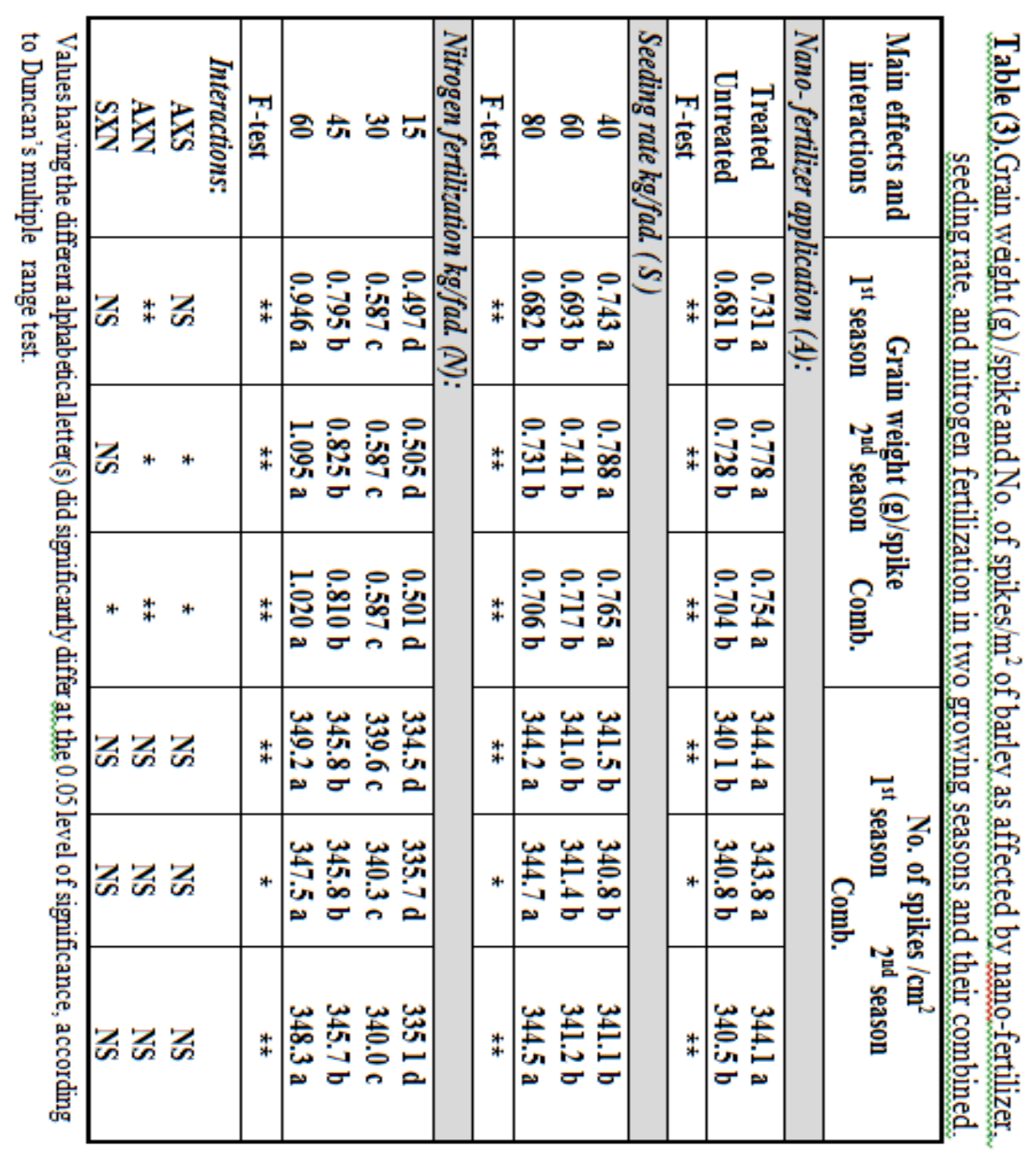




\section{2. c. Nitrogen fertilization effect:}

Grain weight /spike as well as number of spikes $/ \mathrm{m}^{2}$ were significantly increased by each increment of $\mathrm{N}$ fertilizer level from 15 up to $60 \mathrm{~kg} \mathrm{~N} / \mathrm{fad}$. This was the true in both seasons and their combined. In case of $\mathrm{N}$ levels, maximum tillers $/ \mathrm{m}^{2}$ was produced with the application of $60 \mathrm{~kg} \mathrm{~N} /$ ha when compared with other treatments. The probable reason might be that optimum nitrogen availability plays an essential role in plant growth whereas low or very high dose of nitrogen caused reduction in above ground vegetative growth of plant ( Shafi et al., 2011). Similar results were reported by Seadh et al. (2017).

\section{2. d. Interaction effect:}

The interaction effect of nano-fertilizer and seeding rate on grain weight/spike was significant and is shown in Table (3-a).

Application of nano-fertilizer gave heavier grains/spike under the three tested of seeding rates. On other hand, the heaviest grains/spike was achieved due to the interaction effect between the lowest seeding rate $(40 \mathrm{~kg} / \mathrm{fad}$.) and application of nano-fertilizer. Whereas, the lightest grains /spike $(0.691 \mathrm{~g})$ was recorded under the above mentioned seeding rate without application of nanofertilizer.

Table (3-a).Grain weight /spikeas ( $\mathrm{g}$. .) affected by the interaction between nano-fertilizer application and seeding rate (combined data).

\begin{tabular}{|c|c|c|c|}
\hline $\begin{array}{c}\text { Nano- fertilizer } \\
\text { Application }\end{array}$ & \multicolumn{3}{|c|}{ Seeding seed (kg/fad.) } \\
\hline \multirow{2}{*}{ Treated } & $\mathrm{C}$ & $\mathbf{6 0}$ & $\mathbf{8 0}$ \\
\hline \multirow{2}{*}{ Untreated } & $\mathbf{0 . 7 7 2} \mathrm{a}$ & $\mathbf{A}$ & $\mathrm{B}$ \\
& $\mathrm{B}$ & $\mathrm{A} 06 \mathrm{a}$ & $\mathbf{0 . 7 3 6 ~ a}$ \\
\hline
\end{tabular}

Grain weight/spike was significantly influenced by the interaction effect between nano-fertilizer and $\mathrm{N}$ fertilization Table (3-b). The results showed that grain weight/spike responded to nano-fertilizer when $\mathrm{N}$ fertilizer rate reached to 30 and up $60 \mathrm{~kg} / \mathrm{fad}$. However, under the lowest $\mathrm{N}$ rate $(15 \mathrm{~kg} / \mathrm{fad}$.) this weight did not affected.

On the other hand, the rate of increase in grain weight/spike due to each increment of $\mathrm{N}$ fertilization level was much more higher when application of nano-fertilizer was added than without application of nano-fertilizer one.

Also, grain weight/spike was significantly affected by the interaction between seeding rate and $\mathrm{N}$ fertilization Table (3-c). Under the lowest $\mathrm{N}$ fertilization level, any increase in seeding rate from 40 to 60 and to $80 \mathrm{~kg} / \mathrm{fad}$. was accompanied by a significant decrease in grain weight/spike. Meanwhile, 
Table (3-b). Grain weight /spikeas ( g. ) affected by the interaction between nano- fertilizer application and nitrogen fertilization ( combined data).

\begin{tabular}{|c|c|c|c|c|}
\hline $\begin{array}{c}\text { Nano- fertilizer } \\
\text { Application }\end{array}$ & \multicolumn{4}{|c|}{ Nitrogen fertilization (kg N/fad.) } \\
\hline \multirow{2}{*}{ Treated } & $\mathrm{D}$ & $\mathrm{30}$ & $\mathbf{4 5}$ & $\mathbf{6 0}$ \\
& $0.506 \mathrm{a}$ & $0.614 \mathrm{a}$ & $0.850 \mathrm{a}$ & $\mathrm{A}$ \\
& $\mathrm{D}$ & $\mathrm{C}$ & $\mathrm{B}$ & $\mathrm{A}$ \\
Untreated & $0.495 \mathrm{a}$ & $0.561 \mathrm{~b}$ & $0.771 \mathrm{~b}$ & $0.992 \mathrm{~b}$ \\
\hline
\end{tabular}

Table (3-c). Grain weight/spike (g.) as affected by the interaction between seeding rate and nitrogen fertilization ( combined data).

\begin{tabular}{|c|c|c|c|c|}
\hline $\begin{array}{c}\text { Seeding rate } \\
\text { (kg/fad.) }\end{array}$ & \multicolumn{4}{|c|}{ Nitrogen fertilization (kg N/fad.) } \\
\hline \multirow{2}{*}{40} & $\mathrm{D}$ & $\mathrm{30}$ & $\mathbf{4 5}$ & $\mathrm{B}$ \\
& $0.515 \mathrm{a}$ & $0.624 \mathrm{a}$ & $0.850 \mathrm{a}$ & $1.072 \mathrm{a}$ \\
\hline \multirow{2}{*}{60} & $\mathrm{D}$ & $\mathrm{C}$ & $\mathrm{B}$ & $\mathrm{A}$ \\
& $0.508 \mathrm{~b}$ & $0.568 \mathrm{~b}$ & $0.797 \mathrm{~b}$ & $0.995 \mathrm{~b}$ \\
\hline \multirow{2}{*}{$\mathbf{8 0}$} & $\mathrm{D}$ & $\mathrm{C}$ & $\mathrm{B}$ & $\mathrm{A}$ \\
& $0.479 \mathrm{c}$ & $0.570 \mathrm{~b}$ & $0.783 \mathrm{~b}$ & $0.994 \mathrm{~b}$ \\
\hline
\end{tabular}

under the three other $\mathrm{N}$ fertilization rates, this weight was significantly decreased by increasing seeding rate only from 40 to $60 \mathrm{~kg} / \mathrm{fad}$.

\section{Thousand-grain weight (g) and grain yield (ardab/fad.):}

\section{3. a. Nano-fertilizer effect:}

Nano-fertilizer application (Table 4), results indicated significant differences in the first seasons and the combined analysis whereas, application of nano-fertilizer gave heavier 1000-grain than that of without application. In this direction similar conclusions were obtained by Abdel-Aziz, et al.(2016). Janmohammadi et al.(2016b),Kandil and Eman (2017), Morsy et al.(2018) and Ghorbanian et al.(2019). While in the second season, difference between with and without application did not reach the level of significance.

The superiority of nano-fertilizer application in almost the studied all grain yield attributes (Tables 2, 3 and 4) could account for superiority in grain yield/fad. The combined analysis showed that nano-fertilizer application was increased grain yield/fad. with about $7.72 \%$. These results are in agreement with those reported by Abdel-Aziz et al. (2016). They found that all grain yield variables of wheat plants treated with nano-composite NPK fertilizer were increased about $63.82 \%$ for grain yield. The possible reasons are: (i) nano NPK 


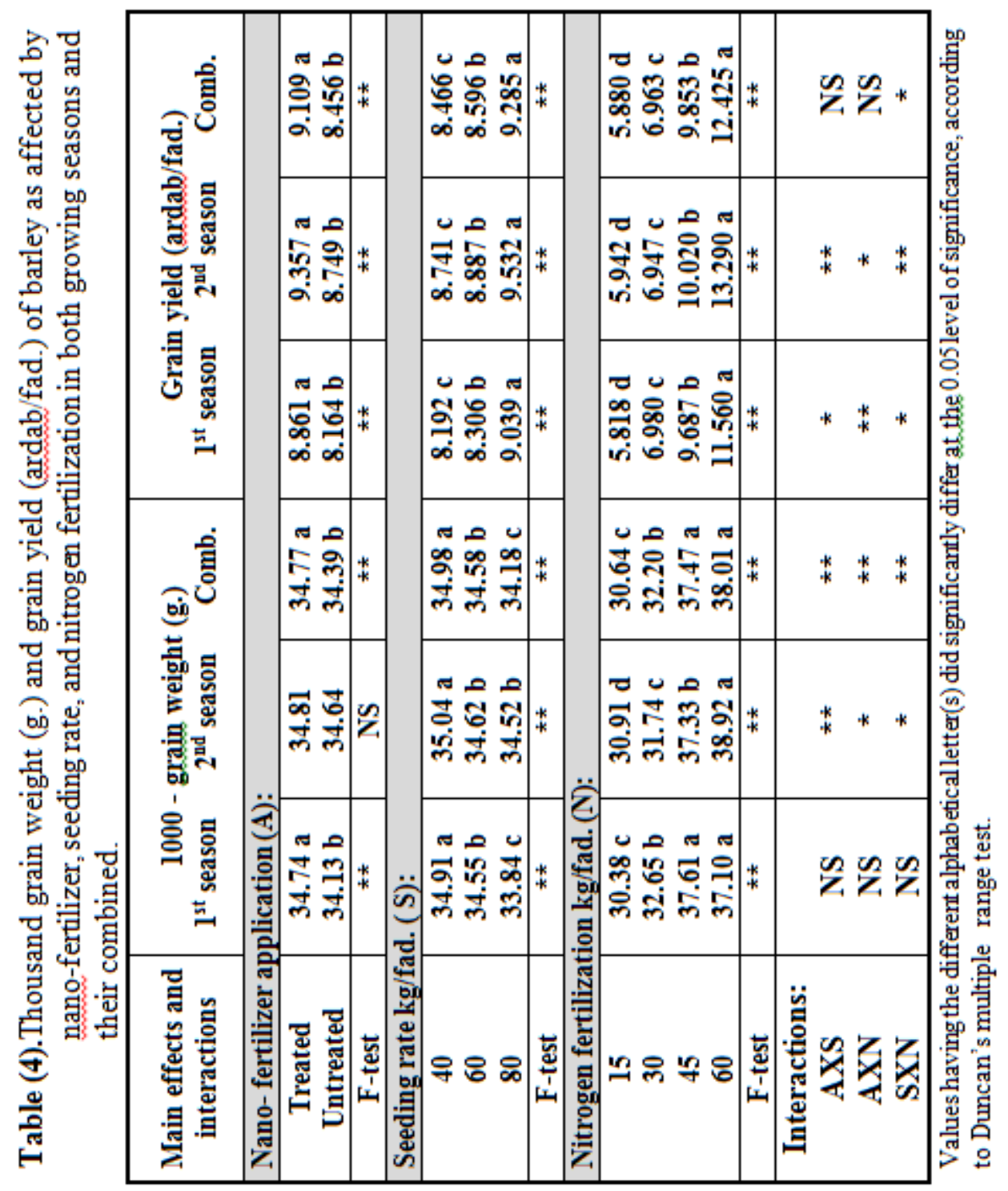


fertilizer promotes the plant to absorb water of soil and nutrients, then the photosynthesis is improved (Wu, 2013); (ii) nano NPK is considered the biological pump for plants to absorb nutrients and water, As reported by Ditta and Arshad (2016), Janmohammadi et al.(2016a), Abdulhady et al.(2018) and Spruogiset al.(2018).

\section{3. b. Seeding rate effect:}

Seeding rate results indicated highly significant differences in both 1000grain weight and grain yield ( ardab / fad.) throughout the both growing seasons and the combined.

In the first season and the combined, 1000-grain weight was significantly decreased by any increase of seeding rate from 40 to 60 andup to $80 \mathrm{~kg} / \mathrm{fad}$. While in the second season this weight was only significantly decreased by raising seeding rate from 40 to $60 \mathrm{~kg} / \mathrm{fad}$.

Bekele et al. (2020) reported that when seeding rate increased from 100$175 \mathrm{~kg} / \mathrm{ha}$ resulted in decreased 1000-grain weight by $23.51 \%$. This could be due to high density caused to increasing number of spikes, and as result of competition would increase and little photosynthesis would available to grain filling and finally 1000-grain weight would reduce due to increasing number of spike. Therefore insufficient photosynthesis during grain filling stage in thick density may be the possible reason to decrease 1000-grain weight. This result is in line with those reported by O'Donovan et al. (2011),Iqbal and Ali (2010), Yasin and Omar (2013) and Mekonnen (2018).

Concerning the influence of seeding rate on grain yield/ fad. the results revealed highly significant differences during both growing seasons and their combined analysis where, the highest seeding rate of $80 \mathrm{~kg} / \mathrm{fad}$. appeared to produce the highest grain yield/fad.. In addition to, each increase in seeding rate from 40 to $80 \mathrm{~kg} / \mathrm{fad}$. was accompanied by a significant increase in grain yield/fad. This was valid in the two seasons and the combined analysis.

The superiority of seeding rate ( $80 \mathrm{~kg} / \mathrm{fad}$. ) over the low and moderate rates of 40 to $60 \mathrm{~kg} / \mathrm{fad}$. amounted to about $1.11 \%$ and $9.67 \%$, in respective order. The increase in in yield with increasing seeding rate is due to more spikes being produced as a result of more plants being established. This explains why maintaining adequate plant populations is important for maximizing grain yields, given the low number of spikes produced, on average/ plants, as well as because tillering can never fully compensate for in adequate plant stands. Higher seeding rates are recommended because they also allow for greater crop competition against weeds.

When a reference is made to the data related to the yield attributes and components, it would revealed that the individual plant showed enhanced 
number of spikelets/spike and number of grains/spike Table (2), grain weight/spike and 1000-grain weight Table (4). The superiority seeding rate in all these mentioned characters was not adequate to compensate for the reduction grain yield/fad. The obtained results agree with findings of Mohammed and Hashem (2012) and Tigabu and Asfadw (2016).

\section{3. c. Nitrogen fertilization effect:}

Regarding the effect of nitrogen fertilizer levels on 1000-grain weight, results showed the highly significant effect of nitrogen on that trait( .1000grain weight ) was positively and significantly responded to $\mathrm{N}$ level up to 45 $\mathrm{kg} / \mathrm{fad}$. in the first season and the combined analysis. While ,in the second season this response was continued up to the highest $\mathrm{N}$ dose $(60 \mathrm{~kg} / \mathrm{fad}$.) . These results are in accordance with those obtained by Shafi et al. (2011), Jankovic et al. (2011), Seadh et al.(2017), Dubey et al.(2018) and Kassie and Tesfadye (2019). Meanwhile, Mengistu and Abera (2014) and Terefe et al. (2018) reported that 1000 seed of malt barley weights had a linear and negative response to $\mathrm{N}$ fertilizer rates and exhibited non-significant difference among control and the rest of applied $\mathrm{N}$ treatments.

Rersults in Table 4 show that, grainyield/ fad. was obviously controlled by nitrogen application. Each increase in nitrogen fertilization doses was followed by a significant increase in this yield. These results were confirmed in both seasons and their combined analysis. The combined results indicated that application of $60 \mathrm{~kg} \mathrm{~N} / \mathrm{fad}$ resulted in increases of 111.2, 78.3 and $26.0 \%$ compared to applying of 15,30 , and $45 \mathrm{~kg} \mathrm{~N} / \mathrm{fad}$, in respective order. The highest value of yield attributing characters were obtained under highest nitrogen level because plants were subjected to utilize the greatest amount of available nitrogen which resulted into increased translocation of photosynthesis from source to sink and thus led to rich growth and various yield attributing characters (Dubeyet al., 2018).

In this investigation, $\mathrm{N}$-fertilization was very effective on all yield characteristics studied viz. number of spikelets and grains/ spike as well as number of spikes $/ \mathrm{m}^{2}$ and weight of both grains/spike and 1000 grain which showed remarkable differences due to various $\mathrm{N}$ level (Tables 2, 3 and 4). All the yield attributes studied herein responded to more $\mathrm{N}$ application up to $60 \mathrm{~kg}$ $\mathrm{N} / \mathrm{fad}$. These findings are in harmony with those reported by Ryan et al.(2009), Safina (2010), Gezahegn and Kefadle (2016), Morsyet al.(2018), Terefeet al. (2018) and Awulachew (2019).

This might be due to the good influence of that major element on the growth traits and the attributing characteristics of barley grain yield. Also, it might be due to cumulative effect of growth and yield attributing characters 
owing to fertilization. Greater availability of metabolites and nutrients to developing reproductive structures seems to have resulted in increase in all the yield-attributing characters which ultimately improved the yield of the crop Singh et al.(2010). The increase in grain yield in response with increasing rate of nitrogen could be attributed to enhanced availability of the nutrient for uptake by the plants and increased photo-assimilate production that would eventually lead to improved partitioning of carbohydrate to the grains (Gooding and Davies, 1997).

\section{3. d. Interaction effect:}

Respecting the significant interaction effects among the studied fadctors regarding the combined results, the interaction effect between nano-fertilizer application and seeding rate (Table 4-a) indicated that the heaviest 1000 grain was achieved with nano-fertilizer under the lowest seeding rate $(35.21 \mathrm{~g})$ whereas, the lightest 1000 -grain was obtained without nano-fertilizer under the highest seeding rate (34.0 g). Only a significant difference in 1000-grain weight between with and without nano-fertilizer was showed under the lowest seeding rate.

On the other hand, 1000-grain weight was significantly decreased by raising seeding rate above $40 \mathrm{~kg} / \mathrm{fad}$. under with nano-fertilizer however, under without nano-fertilizer that weight was gradually decreased by raising rate from 40 to 60 and up to $80 \mathrm{~kg} / \mathrm{fad}$.

Table (4-a). Thousand grain weight (g.) of barley as affected by the interaction between nano-fertilizer application and seeding rate (combined data).

\begin{tabular}{|c|c|c|c|}
\hline $\begin{array}{c}\text { Nano- fertilizer } \\
\text { Application }\end{array}$ & \multicolumn{3}{|c|}{ Seeding seed (kg/fad.) } \\
\hline \multirow{2}{*}{ Treated } & A & 60 & B \\
& 35.21 a & B & B \\
\multirow{2}{*}{ Untreated } & A & AB & 34.36 a \\
\hline
\end{tabular}

Furthermore, the significant interaction effect between nano-fertilizer application and $\mathrm{N}$ fertilization Table (4-b), the results showed that 1000 grain weight was significantly increased only by nano-fertilizer under the $\mathrm{N}$ levels 45 and $60 \mathrm{~kg} / \mathrm{fad}$. Adding nano-fertilizer and the highest $\mathrm{N}$ rate produced the heaviest 1000 grain while, without nano-fertilizer with the lowest $\mathrm{N}$ level was recorded the lightest one. 
Table (4-b). 1000- grain weight (g.) of barley as affected by the interaction between nano-fertilizer application and nitrogen fertilization (combined data).

\begin{tabular}{|c|c|c|c|c|}
\hline \multirow{2}{*}{$\begin{array}{l}\text { Nano- fertilizer } \\
\text { Application }\end{array}$} & \multicolumn{4}{|c|}{ Nitrogen fertilization (kg N/fad.) } \\
\hline & & 30 & 45 & \\
\hline Treated & $\begin{array}{c}\mathrm{C} \\
30.89 \mathrm{a}\end{array}$ & $\begin{array}{c}\text { B } \\
32.14 \mathrm{a}\end{array}$ & $\begin{array}{c}\text { A } \\
37.79 \\
\mathrm{a}\end{array}$ & $\underset{38.27}{A} \mathrm{a}$ \\
\hline Untreated & $\begin{array}{c}\mathrm{C} \\
30.40 \mathrm{a}\end{array}$ & $\begin{array}{c}\text { B } \\
32.25 \mathrm{a}\end{array}$ & $\begin{array}{c}\text { A } \\
37.15 ~ b\end{array}$ & $\begin{array}{c}\text { A } \\
37.75 ~ b\end{array}$ \\
\hline
\end{tabular}

Finally, the significant interaction effect between seeding rate and $\mathrm{N}$ fertilization Table (4-c), indicated that the heaviest 1000 grain $(38.92 \mathrm{~g})$ was obtained by using the moderate seeding rate with the highest $\mathrm{N}$ level. Meanwhile, using the heaviest seeding rate with the lowest $\mathrm{N}$ level recorded the lightest 1000- grains (30.22 g).

Under application of 30 and $45 \mathrm{~kg} \mathrm{~N} / \mathrm{fad}$., 1000-grain weight was significantly decreased by raising seeding rate much more $40 \mathrm{~kg}$ seed/fad., however under the highest $\mathrm{N}$ level this weight took the opposite trend by raising seeding rate only up to $60 \mathrm{~kg} / \mathrm{fad}$.

It is evident that, the rate of increase in 1000- grain weight due to each increment of $\mathrm{N}$ level was much more higher when $60 \mathrm{~kg}$ seed/fad was used $(2.74 \mathrm{~g})$ than in the two other seeding rates 2.59 and $2.26 \mathrm{~g}$ for 40 and $80 \mathrm{~kg}$ seed/fad., respectively.

Table (4-c). 1000- grain weight (g.) of barley as affected by the interaction between seeding rate and nitrogen fertilization ( combined data).

\begin{tabular}{|c|c|c|c|c|}
\hline $\begin{array}{c}\text { Seeding rate } \\
\text { (kg/fad.) }\end{array}$ & \multicolumn{4}{|c|}{ Nitrogen fertilization (kg N/fad.) } \\
\hline \multirow{2}{*}{40} & $\mathrm{C}$ & $\mathrm{B}$ & $\mathbf{4 5}$ & $\mathbf{6 0}$ \\
\hline \multirow{2}{*}{60} & $31.03 \mathrm{a}$ & $33.33 \mathrm{a}$ & $\mathbf{3 8 . 2 5} \mathrm{a}$ & $\mathbf{3 7 . 3 1} \mathrm{b}$ \\
\hline \multirow{2}{*}{80} & $\mathrm{C}$ & $\mathrm{C}$ & $\mathrm{B}$ & $\mathrm{A}$ \\
& $30.69 \mathrm{a}$ & $31.30 \mathrm{~b}$ & $37.43 \mathrm{~b}$ & $38.92 \mathrm{a}$ \\
\hline & $\mathrm{D}$ & $\mathrm{C}$ & $\mathrm{B}$ & $\mathrm{A}$ \\
& $30.22 \mathrm{a}$ & $31.30 \mathrm{~b}$ & $\mathbf{3 6 . 7 4} \mathrm{b}$ & $37.80 \mathrm{~b}$ \\
\hline
\end{tabular}

Grain yield/fad was significantly affected by the interaction between seeding rate and $\mathrm{N}$ fertilization. This was true for grain yield/fad. in both seasons and their combined. Results in Table (4-d) show the effect of this interaction on grain yield /fad., according to the combined analysis. 
It is obvious that with application of $\mathrm{N}$ fertilizer much more the lowest dose ( $45 \mathrm{~kg}$./fad. ) grain yield/fad. positively and significantly responded only to the highest seeding rate. Whereas, under the lowest $\mathrm{N}$ dose this yield was positively and significantly increased by any increment in seeding rate up to 80 $\mathrm{kg} / \mathrm{fad}$. The highest grain yield /fad. was achieved by using the highest seeding rate $(80 \mathrm{~kg} / \mathrm{fad}$.) with application of the highest $\mathrm{N}$ dose $(60 \mathrm{~kg} \mathrm{~N} / \mathrm{fad}$.). Whereas, the lowest grain yield was recorded by the lowest seeding rate under the lowest $\mathrm{N}$ level.

Table (4-d). Grain yield (ardab/fad.) of barley as affected by the interaction between seeding rate and nitrogen fertilization (combined data).

\begin{tabular}{|c|c|c|c|c|}
\hline \multirow{2}{*}{$\begin{array}{c}\text { Seeding rate } \\
\text { (kg/fad.) }\end{array}$} & \multicolumn{4}{|c|}{ Nitrogen fertilization (kg N/fad.) } \\
\hline & 15 & 30 & 45 & 60 \\
\hline 40 & $\begin{array}{c}D \\
5.590 \mathrm{c}\end{array}$ & $\begin{array}{c}C \\
6.701 \mathrm{~b}\end{array}$ & $\begin{array}{c}\text { B } \\
9.515 \mathrm{~b}\end{array}$ & $\begin{array}{c}A \\
12.060 \mathrm{~b}\end{array}$ \\
\hline 60 & $\begin{array}{c}\text { D } \\
5.957 \mathrm{~b}\end{array}$ & $\begin{array}{c}\mathrm{C} \\
6.752 \mathrm{~b} \\
\end{array}$ & $\begin{array}{c}\text { B } \\
9.600 \mathrm{~b}\end{array}$ & $\begin{array}{c}\mathrm{A} \\
12.070 \mathrm{~b}\end{array}$ \\
\hline 80 & $\begin{array}{c}D \\
6.095 \mathrm{a}\end{array}$ & $\begin{array}{c}\mathrm{C} \\
7.438 \mathrm{a}\end{array}$ & $\begin{array}{c}\text { B } \\
10.450 \text { a }\end{array}$ & $\begin{array}{c}\mathrm{A} \\
13.150 \mathrm{a}\end{array}$ \\
\hline
\end{tabular}

\section{Conclusion}

This investigation was carried out on barley with the hope of increasing grain yield through a complementary effect could be traced between application of nano-fertilizer, seeding rate and nitrogen fertilization specially under Sinai conditions and changes in climate fadctors. Application of nano-fertilizer appeared to produce the highest value in No. of both spikelets and grains/ spike as well as weight of grains/spike, 1000- grain weight and grain yield/fad. The seeding rate of $80 \mathrm{~kg} / \mathrm{fad}$. appeared to produce the highest values in each of number of spikes $/ \mathrm{m}^{2}$ and grain yield/fad. Meanwhile, the seeding rate of $40 \mathrm{~kg} / \mathrm{fad}$. recorded the highest values in No. of both spikelets and grains/ spike, weight of both grains/spike and 1000-grain. Nitrogen fertilization was very effective on all yield characteristics, so any increase in $\mathrm{N}$ levels was followed by a significant increase in each of No. spikelets/spike, grains/spike and spikes $/ \mathrm{m}^{2}$, also weight of both grains/spike and 1000 grain weight.

These results finally recommend sowing barley with dense seeding rate of $80 \mathrm{~kg} / \mathrm{fad}$. and application of $60 \mathrm{~kg} \mathrm{~N} / \mathrm{fad}$. In addition to application of nano-fertilizer to maximize grain yield /fad. under the experimental site and other likely environmental conditions. 


\section{REFERENCES}

Abdel-Aziz, M. M. Heba; M. N. A. Hasaneen and Aya M. Omer (2016).Nano chitosan-NPK fertilizer enhances the growth and productivity of wheat plants grown in sandy soil. Spanish J. of Agric. Res., Vol. 14 (1), e 0902, 9 pages.

Abdel-Hady,Safada,M.H.(2018).Response of some wheat cultivars to varying sowing date and planting densities. M.Sc. Thesis, Fadc. of Agric., Zagazig Univ. Egypt.

Abdulhady, Y. A. M.; H.A. Hanan, and A. L. Saleh (2018).Effect of Treated Irrigating Water by Iron Nanoparticles and (MINP) Coated with (NPK) as Foliar Nano-Fertilizer on Wheat Grains (Triticum aestivium L.) Yields (El Fadyum-Egypt) . Australian Journal of Basic and Applied Sci., 12(9): 146-156.

Abobatta, F. A. (2018). Nanotechnology application in agriculture. Acta Scientific Agric., 2 (6): 99-102.

Amarjeet; B. Singh; J. Kumer; M. Kumar, R. Sharma and P. Kaushik (2020). Effect of sowing date, seed rate and row spacing on productivity and profitability of barley (Hordeumvulgare L.) in North India. Posted 31 January 2020. ,Doi: 10.20944/ preprients 202001.0380. v1.

Assefad, W., N. Yemane and H. Dawit (2015).Planting density and nitrogen and phosphorus fertilization effect on different bread wheat (Triticum aestivum L.) genotypes in Southern Tigray, Ethiopia. World J. of Sci. and Res., 3 (2): 20-28.

Awulachew, M. T. (2019). Productivity and grain quality of Holker, Ibon and Franka malt barley (Hordeum vulgare L.) varieties to the rate of nitrogen fertilizer at Central Highland of Arsi. Ethiopia. J. Sci., 2: 12.

Bekele, S.; T. Yoseph and T. Ayalew (2020). Growth, protein content, yield and yield components of malt barley (Hordeum vulgare L.) varieties in response to seeding rate at Sinana District, Southeast Ethiopia. Int. J. of Appl. Agric. Sci ., 6 (4): 61-71.

Ditta,A. and M.A. rshad (2016). Applications and specters of using nanomaterial's for sustainable plant nutrition. Nanotechnol Rev., 5(2): 209-229.

Dubey, S.; A. Tiwari and V. Singh (2018). Effect of nitrogen levels and its time of application on yield attributes, yield and economics of barley (Hordeum vulgare L.). Int. Curr. Microbiol. App. Sci., Vol. 7 (1): 16951705.

Duncan, D.B. (1955). Multiple Range and Multiple F-test. Biometrics, 11:142. 
Gezahegn, B. and D. Kefadle (2016). Effect of Nitrogen Fertilizer Level on Grain Yield and Quality of Malt Barley (Hordeumvulgare L.) Varieties in MalgaWoreda, Southern Ethiopia. Food Science and Quality Management, 52: 8 -16.

Ghorbanian, H.; Janmohammadi, M.; Ebadi-Segherloo, A. and N. Sabaghnia (2019). Genotypic response of barley to exogenous application of nanoparticles under water stress condition. Biologia Annals Umcs. P I, Vol. 18: 18-30.

Iqbal, A. and M. Ali (2010). Effect of seed rate and row spacing on yield and yield components of wheat (Triticum aestivum L.), Adaptive Res. Fadrm, Vehari, Pakistan. J. Agric. Res., 48 (2): 151-156.

Jankovic, S.; D. Glamoclija; R. Maletic; S. Rakic; N. Hristov and J. Ikanovic (2011).Effect of nitrogen fertilization on yield and grain quality in malting barley. African J. Biotech., 10 (84): 1934-1941.

Janmohammadi, M.; N. Sabaghnia and S. Dashti and M. Nouraein (2016 b).Investigation of foliar application of nano- micronutrient fertilizers and nano-titanium dioxide on some traits of barley. Biologija, Vol. 62 (2): $148-156$.

Janmohammadi, M.; T. Amanzadeh, N. Sabaghnia and S. Dashti (2016 b).Impact of foliar application of nano micronutrient fertilizers and titanium dioxide nanoparticles on growth and yield components of barley under supplemental irrigation. Acta Agric. Slovenica, 107 (2): 265-276.

Kandil, E. E. and A. O. M. Eman (2017). Response of some wheat cultivars to nano mineral fertilizers and amino acids foliar application. Alex.Sci. Exchange Journal, 38(1): 53-68.

Kassie, M. and K. Tesfadye (2019). Malting barley grain quality and yield response to nitrogen fertilization in the Arsi Highlands of Ethiopia. Crop Sci. Biotech., Vol. 22 (3): 225 - 234.

Liu, R. and R. Lal (2015). Potentials of engineered nanoparticles as fertilizers for increasing agronomic productions. Science of The Total Environment, 514C:131-139- DOI: 10.1016/ J. Scitotenv. 01.104.

Malcolmson, N., Nowkirkm, R. and G.Carson (2005). Expanding opportunities for barley food and geed through product innovation. Feed and food quality; 18th National American Barley Research Workshop 4th Canadian Barley Symposium, pp 2-4.

Mardalipour, M., H. Zahedi and Y. Sharghi (2014). Evaluation of nanobiofertilizer efficiency on agronomic traits of spring wheat at different sowing date.. Biological Forum - An International Journal, 6(2): 349-356. 
Mekonnen, L. (2018). Effect of seed and $\mathrm{N}$ rate on grain yield and yield components of barley. J. of Natural Sci. Res., 8 (3): 10-15.

Mengistu, D.K. and F. A. Abera (2014). Growth and yield of barley (Hordeum vulgare L.) as effected by nitrogen and phosphorus fertilization and water regimes in Tigray, Ethiopia Momona. Ethiopia Journal of Science, 6 (1): 45:57.

Moaveni P., Talebi A., Fadrahani A., Maroufi K. (2011). Study of nano particles $\mathrm{TiO}_{2}$ spraying on some yield components in barley (Hordem vulgare L.), Intl. Conf. Environ. Agri. Eng. IPCBEE, 15 (Jurong West: IACSIT Press), 115-119.

Mohammed A. K. I.and M. H. Hashem (2012). Effect of seeding rate and potassium on growth and yield of barley. Iraq J. of Agric./ Sci.,43(5): 3341.

Morsy, A. S. M.; A. Awadalla and M. M. Sherif (2018).Effect of irrigation, foliar spray with nano- fertilizer (Lithovit) and N-levels on productivity and quality of durum wheat under Tochka conditions. Assiut J. Agric. Sci. , 49 (3): 1-26.

Mousavi-FadzlSH. and,F.Fadeznia (2008) Effect of different moisture regimes and nitrogen on the yield and nitrate concentrations in potato tubers. Iran J. Soil Res., 22(2):243-250.

Niguse, K. and M. Kassaye (2018). Response of food barley (Hordeum vulgare L.) varieties to rates of nitrogen fertilizer in Limo District, Hadiya Zone, Southern Ethiopia. J. of Natural. Sci. Res., 8 (5): 17-31.

Noworolnik, K. (2010). Effect of sowing rate on yields and grain quality of new cultivars of spring barley. Polish J. of Agron., 3: 20-23.

O'Donovan, J.; T. Turkingronb, M. Edneyc; G. Claytond; R. Mckenziee; P.E. Patriciaf; G.P. Lafond; C.A. Granth; S. Brandti; K. N. Harkerj; E.N. Johnsonk and W. E. May (2011). Seed rate nitrogen rate, and cultivar effects on malting barley. Crop Agric. J. , 103 (3): 709-716.

Safina, S. A. (2010). Effect of nitrogen levels on grain yield and quality of some barley genotypes grown on sandy soil and salinity irrigation. Egypt. Journal of Agron. , Vol. 32 (2): 207-222.

Seadh, S. E.; A. T. El-Kassaby; M. Monsour and M. M. M. El-Waseef (2017). Effect of foliar application and N-levels on productivity and grains quality of barley. J. Plant Prod, Mansoura Univ., 8 (9):929-933.

Shafi, M.; J. Bakht; M. A. Khan and G. Khattak (2011). Effect of nitrogen application yield and yield components of barley (Hordeum vulgare L.). Pak. J. Bot. , 43 (3): 1471-1475. 
Singh A; Agrawal M. and FM. Marshall (2010). The role of organic vs. inorganic fertilizers in reducing phyto availability of heavy metals in a wastewater-irrigated area. Ecological Engineering, 36:1733-1740.

Spruogis, V.; E. Jakiene; A. Dautarte and R. Zemeckis (2018). The influence of bioorganic nano fertilizer on spring barley and oilseed rape productivity and economical effectiveness. Zemes Ukio Mokslai, Vol. 25 (1): 18-26.

Tanaka, R. and H. Nakano (2019). Barley yield response to nitrogen application under different weather conditions. Sci. Reports, 9: 8477, doi.Org/1038/s41598-o19-44876-y.

Terefe, D.; T. Desalegn and H. Ashagre (2018). Effect of nitrogen fertilizer levels on grain yield and quality of malt barley (Hordeumvulgare L.) varieties at Wolmera District, Central Highland of Ethiopia. Int. J. of Res. Stud. In Agric. Sci. , 4 (4): 29-43.

Tigabu, R. and F. Asfadw (2016). Effects of Seed Rate and Row Spacing on Yield and Yield Components of Bread Wheat (Triticum aestivum L.) in Dalbo Awtaru Woreda, Wolaita Zone, Southern Ethiopia. Journal of Biol., Agric. Health, 6(7): 58-67.

Tigre W.; Worku, W. and W. Haile (2014). Effects of nitrogen and phosphorus fertilizer levels on growth and development of barley (Hordeum vulgare L.) at Bore District, Southern Oromia, Ethiopia. Ame. Journal of Life Sci., 2(5), 260-266.

Yasin, M.A.T. and A.E.A. Omar (2013).Effect of sowing methods, seeding rate and chemical herbicides on wheat under sandy soil condition. Zagazig J. Agric. Res., 40 (6):1045-1057. 


\section{تأثير سماد النانو ومعدل التقاوي والتسميد التيتروجيني على محصول

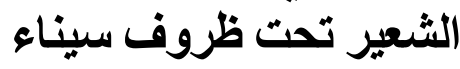

السيد السيد حسن - على عبدالعظيم سرحان - السيد بيومي جاب الله -

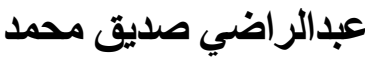
قسم الانتاج النباتي ـ كلية التكنولوجيا وحلي التنمية ـ جامعة الزقازيق ـمصر

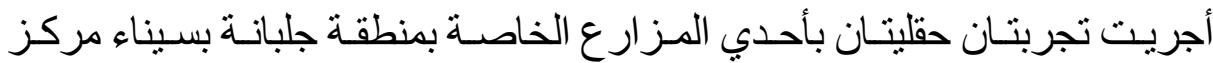

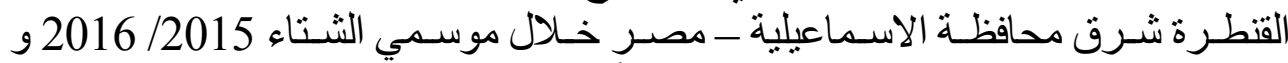

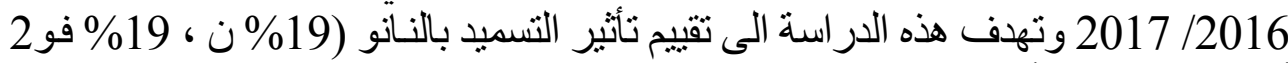

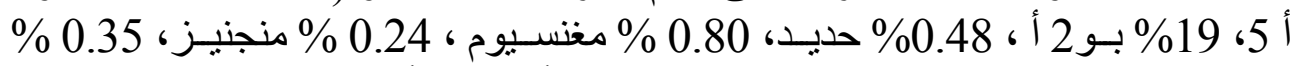

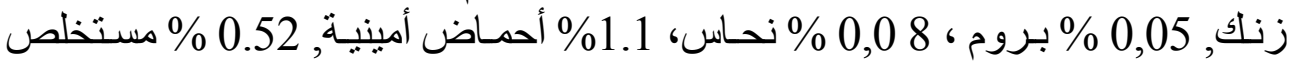

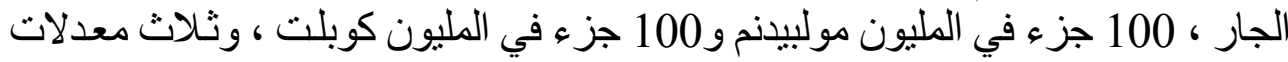

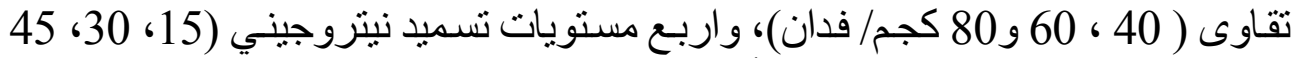

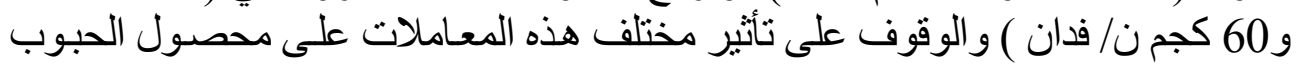
ومكوناته لصنف الثعير جيزة 132. كان التصميم التجريبي هو القطع المنشقة مرتين في قطاعات كاملـة العشو ائية بثناثلث

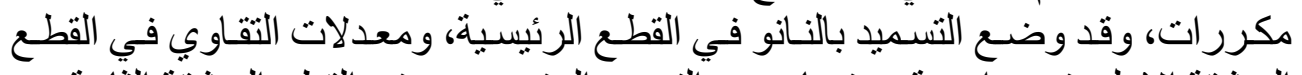
المنثقة الاولى تحت اربعة مستويات من التسميد النيتروجيني في القطع المنثقة الثانية.

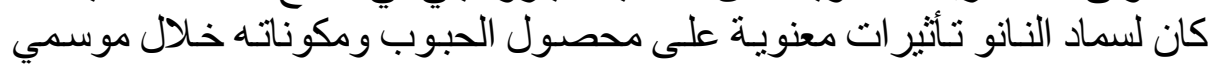

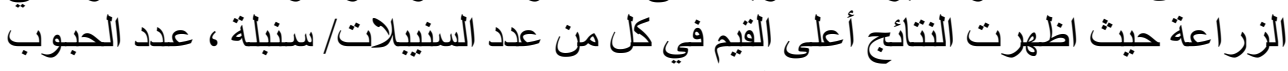

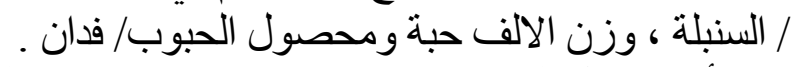

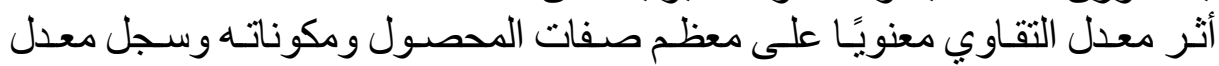

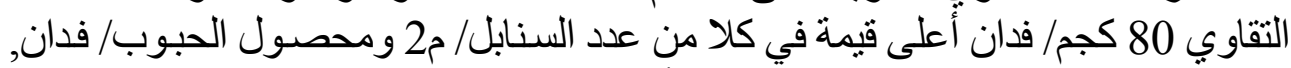

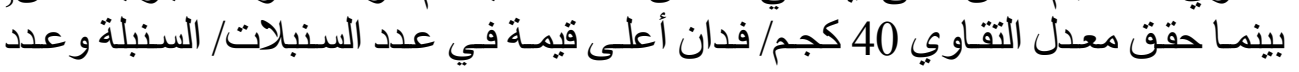
الحبوب بالسنبلة.

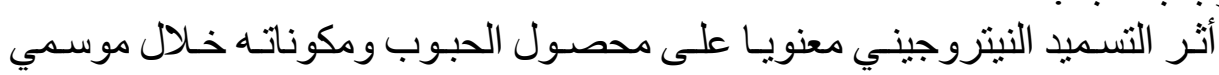
الزراعة حيث ازدادت قيمتهم معنويا بزيادة مستويات التسميد في كلا من عند عدد السنيبيلات/

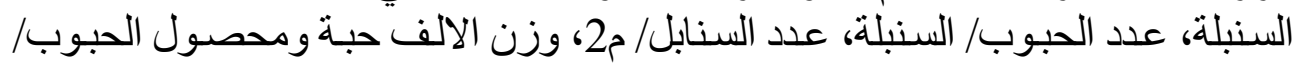
التوصية: توصى الدراسة بزر اعة محصول الثعير صنف جيزة 132 بمعدل 80 كجم/

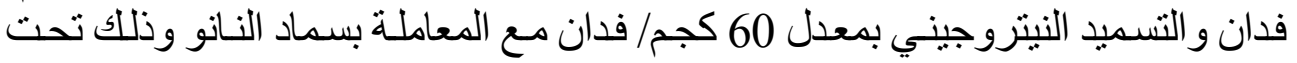
ظروف منطقة سيناء. 